\title{
Seismic Response of a Historical Masonry Bridge under Near and Far-fault Ground Motions
}

\author{
Alper Özmen ${ }^{1}$, Erkut Sayın ${ }^{2 *}$ \\ ${ }^{1}$ Department of Civil Engineering, Engineering Faculty, Inonu University, 44000, Malatya, Turkey \\ 2 Department of Civil Engineering, Engineering Faculty, Firat University, 23119, Elazı $\breve{g}$, Turkey \\ * Corresponding author, e-mail: esayin@firat.edu.tr
}

Received: 11 January 2021, Accepted: 18 April 2021, Published online: 27 April 2021

\begin{abstract}
Historical masonry arch bridges which might be vulnerable to natural disasters are important part of the cultural heritage. Natural disasters, especially earthquakes can inflict damage to these structural systems. This paper aims to investigate a comparison of the effects of near and far-fault ground motions on the seismic response of masonry arch bridges under different earthquakes. Kalender masonry arch bridge which is located in Ergani, Turkey is selected as a numerical model. For this purpose, three-dimensional finite element model of the bridge is generated with ANSYS finite element software with macro modelling approach. Seismic response of the bridge is assessed by means of time-history analyses. The near-fault and far-fault ground motions, which have approximately equal peak ground accelerations, of 1979 Imperial Valley, 1999 Chi-Chi, 1999 Kocaeli and 2010 Darfield earthquakes are considered for the analyses. Comparisons between maximum displacements, maximum and minimum stress, which were acquired from the dynamic analyses of the masonry bridge subjected to each fault effect, are obtained. The study demonstrates that far-fault ground motions are as important as near-fault ground motions and it can be used together with near-fault ground motion for further evaluation of such historical masonry bridges.
\end{abstract}

Keywords

historical stone arch bridges, three-dimensional finite element method, dynamic analyses, near and far-fault ground motions, seismic response

\section{Introduction}

Historical masonry bridges are civil engineering structures that generally have a complex geometry. These bridges, which survived from past to present without losing their significance, provided great conveniences for humanity in terms of transportation and constituted vital importance in the transportation of humans, animals, and mechanical vehicles, are one of the most significant structures of our cultural heritage. Historical masonry arch bridges carry reflections from different centuries. They provide us with clues about the life and knowledge of past generations. These historical structures dating back centuries are damaged due to natural disasters or human intervention. Loss of strength in construction materials depending on time, excessive or irregular loads due to use out of design, earthquakes, settlements, flood disasters, fires and wars played significant roles in damaging or destroying historical masonry arch bridges. Today, in restoration and preservation of historical structures, the structural behaviors of these structures should be determined at first. Especially in terms of bridges, the behavior in the face of earthquakes, which is one of the most significant causes of damages, is important. Historical masonry arch bridges consist of various parts.

The basic parts of the masonry bridges are arch, spandrel wall, infill material and foundation. Arch is possibly the oldest architectural shape, and it is most significant part of the masonry bridges [1]. In the literature, there were different studies about structural assessment of historical masonry bridges. But there is not enough study on the effects of near and far-fault ground motions on seismic assessment of historical masonry arch bridges. When the recent studies are examined, various engineering structures such as tunnels, nuclear station, bridges, dams, and buildings were investigated in terms of near fault and farfault ground motions [2-4]. Near-fault ground motions are described with larger velocity pulse. This situation causes 
high input energy in the structures at the beginning of the ground motion, and it can potentially increase the structural damages. But far-fault ground motions are responsible smaller pulse velocities, and they usually cause resonance effect especially for medium to high structures [5-7]. Zhang and Wang [8] modeled the Koyna gravity dam with two-dimensional finite element method in India to compare the near and far-fault effect. They found that the near-fault earthquake records increased displacements and stresses of the dam and caused more damages.

Liao et al. [2] made non-linear dynamic analysis to compare response of seismically isolated and non- isolated bridges subjected to near-fault and far-field ground motions. They obtained that far-field ground motion is more significant than near-fault ground motion at the effects in base shear reduction of seismically isolated bridge. Adanur et al. [9] compared the effect of near and far-fault ground motions on two-dimensional finite element models of Fatih Sultan Mehmet and Bosphorus bridges in Istanbul. As a result of the study, it was seen that the near fault effect will be more dangerous than the far-fault effect. Chopra and Chintanapakdee [5] compared near-fault and far-fault ground motions on single degree of freedom systems. In the single degree of freedom systems with the same degree of ductility, it is observed that near-fault ground motions cause greater stress than far-fault ground motion. Güllü and Karabekmez [6] investigated near-fault and far-fault earthquake effect on the seismic behavior of a complex historical masonry mosque. The study shows that the far- fault and near-fault ground motions can be used together for investigation of historical mosques for future considerations. Bayraktar and Hökelekli [7] investigated the effects of nonlinear foundation soil behavior on the seismic damage mechanisms of semicircular brick and stone arch bridge. They used the Concrete Damage Plasticity (CDP) and Mohr-Coulomb failure criteria for the nonlinear behaviors of masonry units and homogenous soil domain.

In this study, near-fault and far-fault ground motion effects is investigated on seismic response of a historical masonry bridge. For this purpose, Kalender masonry bridge which is located in Ergani, Turkey is chosen for the numerical analyses. Three-dimensional finite element model is used to model the masonry bridge. Dynamic analyses are performed for near-fault and far-fault ground motions on seismic responses of the historical bridge. The 1979 Imperial Valley, 1999 Chi-Chi, 1999 Kocaeli and 2010 Darfield earthquakes are considered in which the near- fault and far-fault strong ground motion records are used. Structural analyses are performed by ANSYS finite element software. According to the knowledge of the authors, the historical bridge analyzed in this study, despite being an important part of the cultural heritage of the region, has not been investigated before.

\section{Near-fault and far-fault ground motions}

Pulse type characteristic is one of the most important properties of near-fault ground motions. From the strong ground movement records of the past earthquakes (2010 Darfield, 1999 Kocaeli, 1995 Kobe, 1994 Northridge, 1989 Loma Prieta), it was seen that the near-fault earthquakes observed at near distance earthquake stations (i.e., $<10 \mathrm{~km}$ ) considerably different from the far-fault earthquakes detected at large distances (i.e., more than $20 \mathrm{~km}$ up to about $100 \mathrm{~km}$ ) [2]. In a near-fault earthquake, the strong ground motion records are characterized by larger velocity pulse. At the beginning of the earthquake, it gives high input energy to the structures $[6,10,11]$. For this reason, structural responses can increase with significant structural damage. In addition to this, smaller pulse velocities which are to travel in long distances over long periods of time are observed at far-fault earthquakes. Because of the resonance effect especially for medium to high structures, the periods could be cause structural damage during this traveling [5, 12-13].

In this paper, near-fault ground motion term refers to the ground motion record acquired in the vicinity of an apparent velocity pulse (pulse duration greater than $1.0 \mathrm{~s}$ ), the distance of the fault recording less than $10 \mathrm{~km}$, and the peak ground velocity/peak ground acceleration (PGV/PGA) value greater than 0.1 s. [2-10]. In Fig. 1, it can be seen comparison of velocity time history of the near and farfault strong ground motions [14].

In this study, 4 near-fault and 4 far-fault earthquake records are selected in the analyses. The earthquake records were obtained from the Ministry of Interior Disaster and Emergency Management Presidency (AFAD, 2019) [15] and Pacific Earthquake Engineering Research Center (PEER, 2019) [16]. According to the Interactive Earthquake

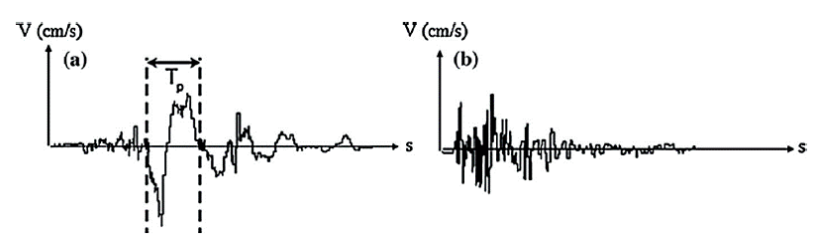

Fig. 1 The time-histories of strong ground motion velocities [14], ( $T_{p}=$ period of velocity pulse) (a) represent typical the near-fault ground motion and (b) represent typical the far-fault ground motion 
Hazard Map of Turkey, these selected earthquake records were scaled to the elastic design spectrum, selecting the location of the bridge.

Seismomatch software was used for scaling the earthquake records [17]. In the analyses, 2010 Darfield, 1999 Kocaeli, 1999 Chi-Chi and 1979 Imperial Valley near-fault and far-fault strong ground motion records were considered. These records were scaled to same peak acceleration $[4,6,2]$. Interactive Earthquake Hazard Map of Turkey and location of the bridge is given in Fig. 2. The properties of the earthquakes to be used in the seismic analysis are given in Table 1.

Acceleration-time, velocity-time, and displacement-time plots of the selected earthquakes are shown in Figs. 3-6. It is seen that the near-fault ground motion is considerably different from the far-fault ground motion when these figures are compared in terms of velocity pulses. When compared with far-fault ground motions, near-fault ground motions have long-period velocity pulse.

\section{Masonry arch Kalender Bridge}

The bridge is located in the Ergani which is town of Diyarbakır. The bridge was built on the Dicle River. Kalender Bridge is located on an important route connecting the Diyarbakır-Harput-Ergani historical road. It is known that there are various inns and bridges around this route, which has been used in the Seljuk and Ottoman during the Byzantine Period. There is no construction or repair epitaph on the Kalender Bridge.

There is no archive record that gives information about its history and there is no ornamental element on the bridge that can be considered as a period sign [18].

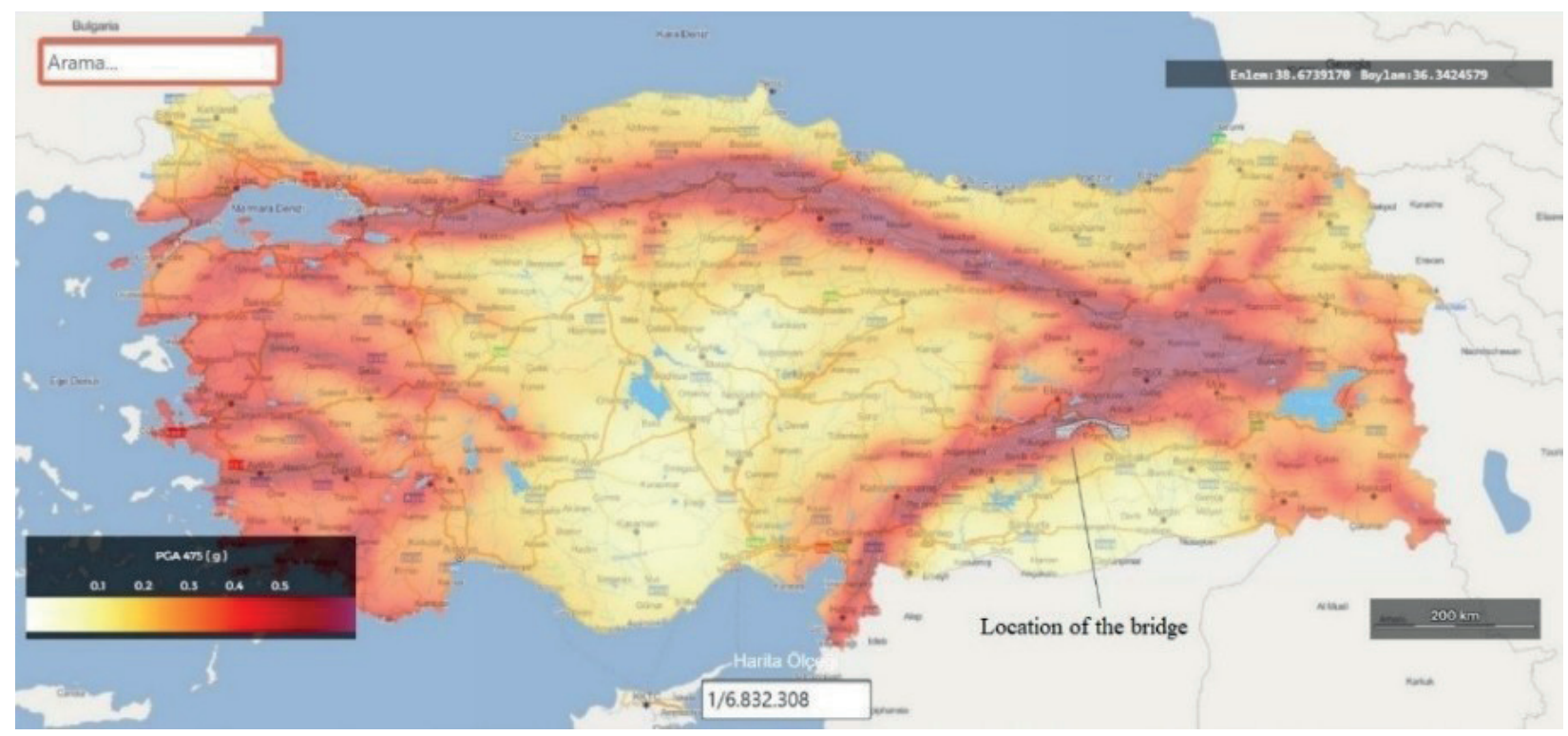

Fig. 2 Turkey Earthquake Hazard Map and location of the Kalender Bridge [16]

Table 1 Properties of selected near-fault and far-fault ground motion records

\begin{tabular}{|c|c|c|c|c|c|c|c|c|c|}
\hline Fault Type & $\begin{array}{c}\text { Earthquake } \\
\text { name }\end{array}$ & Record Station & $\begin{array}{l}\text { Scale } \\
\text { Factor }\end{array}$ & $\begin{array}{l}\mathrm{Vs} 30 \\
(\mathrm{~m} / \mathrm{s})\end{array}$ & $\begin{array}{l}\text { PGA } \\
(\mathrm{g})\end{array}$ & $\begin{array}{l}\text { PGV } \\
(\mathrm{cm} / \mathrm{s})\end{array}$ & $\begin{array}{c}\text { PGV/ } \\
\text { PGA (s) }\end{array}$ & Mw & $\begin{array}{c}\text { Distance to } \\
\text { fault } \mathrm{Rjb}(\mathrm{km})\end{array}$ \\
\hline Near-Fault & $\begin{array}{c}1979 \text { İmperial } \\
\text { Valley }\end{array}$ & $\begin{array}{c}\text { Aeropuerto } \\
\text { Mexical }\end{array}$ & 0.94 & 260 & 0.30 & 42.8 & 0.15 & 6.53 & 0.00 \\
\hline Far-Fault & $\begin{array}{c}1979 \text { İmperial } \\
\text { Valley }\end{array}$ & $\begin{array}{l}\text { Calipatria Fire } \\
\text { Station }\end{array}$ & 2.4 & 206 & 0.30 & 13.69 & 0.05 & 6.53 & 23.17 \\
\hline Near-Fault & 1999 Kocaeli & Yarımca & 1.61 & 297 & 0.27 & 106.44 & 0.40 & 7.51 & 1.38 \\
\hline Far-Fault & 1999 Kocaeli & Bursa (Tofaş) & 3.09 & 290 & 0.27 & 43.67 & 0.16 & 7.51 & 64.95 \\
\hline Near-Fault & 1999 Chi-Chi & CHY\& Chy074 & 1.31 & 534 & 0.29 & 31.84 & 0.11 & 6.2 & 6.02 \\
\hline Far-Fault & 1999 Chi-Chi & CHY\& Chy046 & 2.22 & 442 & 0.28 & 26.76 & 0.09 & 6.2 & 38.11 \\
\hline Near-Fault & 2010 Darfield & HORC\& Horcn18-E & 0.8 & 326 & 0.36 & 59.30 & 0.17 & 7 & 7.29 \\
\hline Far-Fault & 2010 Darfield & FDCS\& Fdcss81-W & 2.65 & 390 & 0.29 & 19.53 & 0.07 & 7 & 90.17 \\
\hline
\end{tabular}


a)
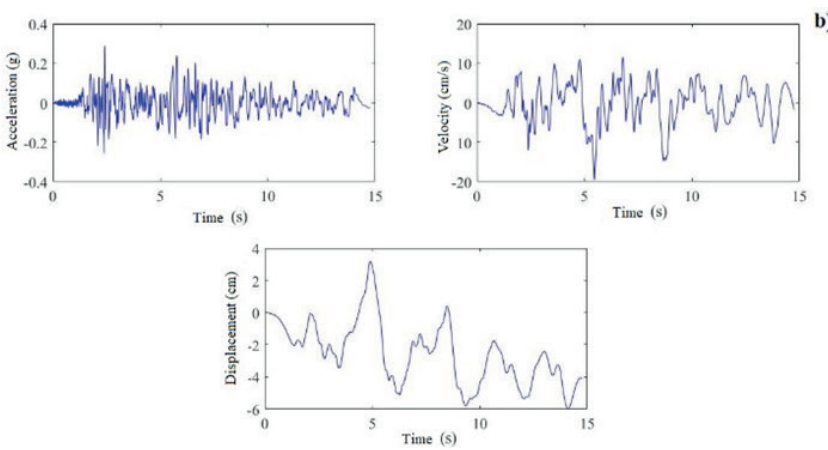
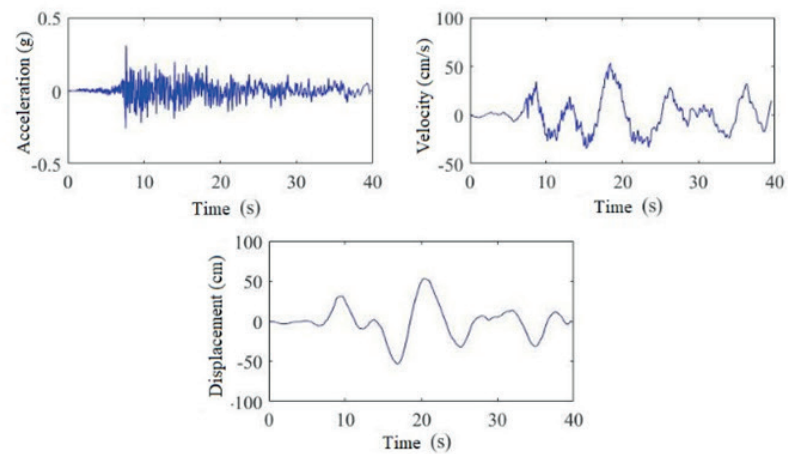

Fig. 3 Acceleration, velocity, and displacement time history graphs of the 1979 Imperial Valley earthquake a) Near-fault ground motion; b) Far-fault ground motion
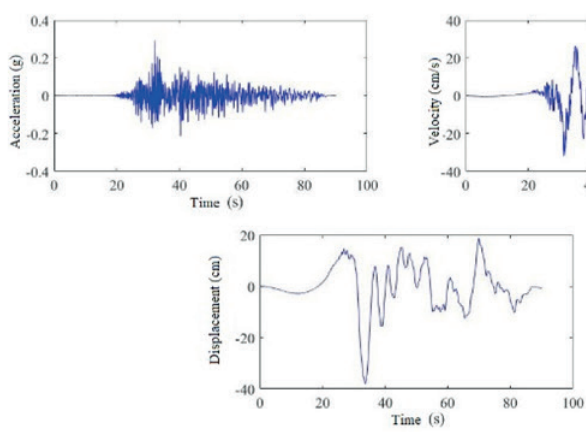
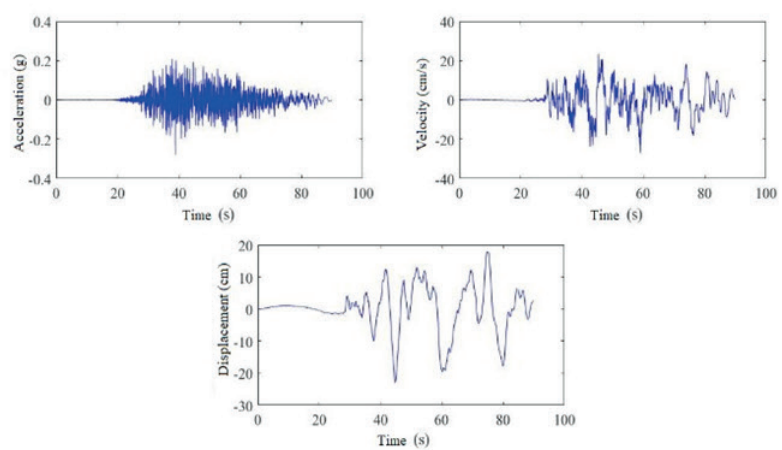

Fig. 4 Acceleration, velocity, and displacement time history graphs of the 1999 Chi-Chi earthquake a) Near-fault ground motion; b) Far-fault ground motion
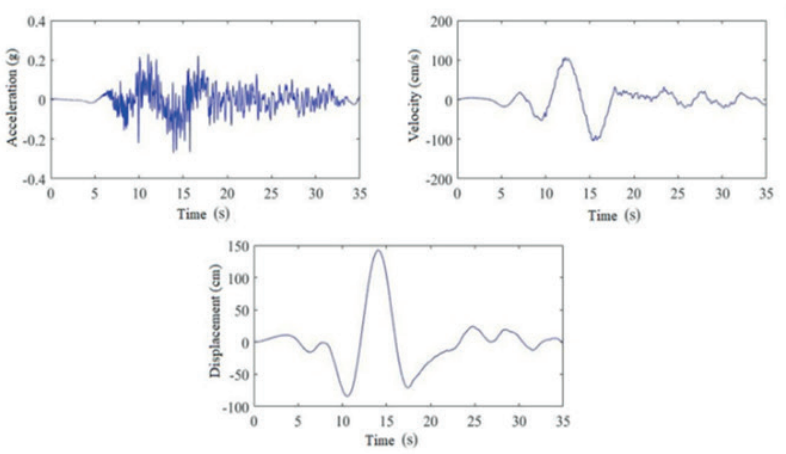
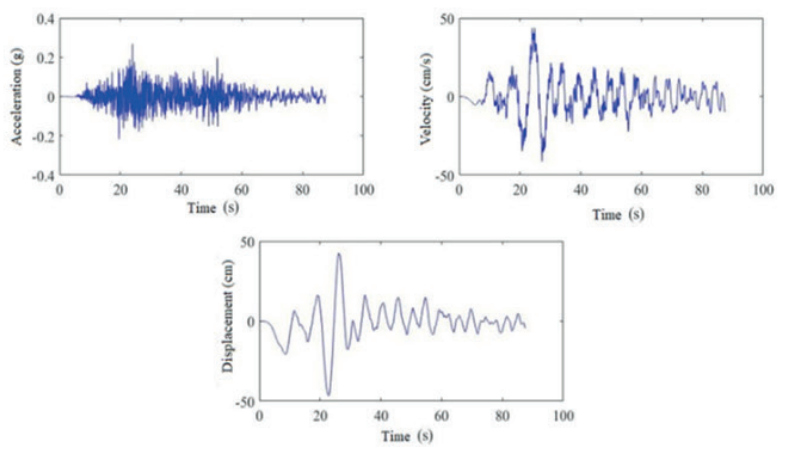

Fig. 5 Acceleration, velocity, and displacement time history graphs of the 1999 Kocaeli earthquake a) Near-fault ground motion; b) Far-fault ground motion
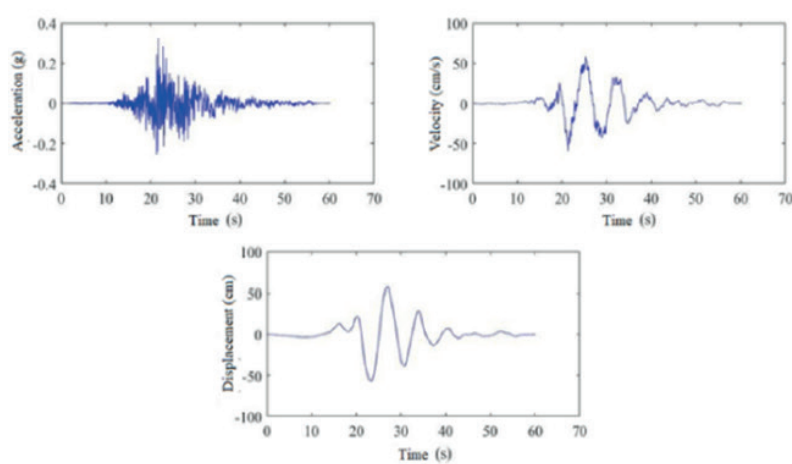
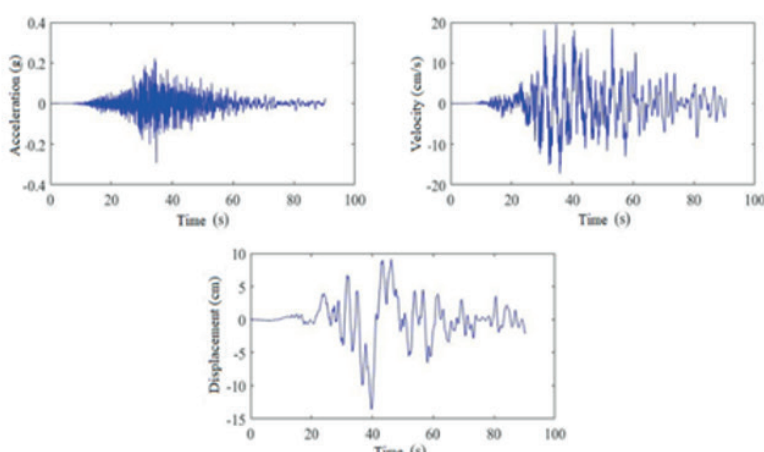

Fig. 6 Acceleration, velocity, and displacement time history graphs of the 2010 Darfield earthquake a) Near-fault ground motion; 
It was seen that the historical masonry arch Kalender Bridge was constructed in 1318 from the sign at the entrance of the bridge. The bridge consists of three arches and these arches have acute arch geometry. Acute arches are generally seen Seljuk architecture. The bridge is $88.80 \mathrm{~m}$ long and $6.35 \mathrm{~m}$ wide. The arch spans of the bridge are $9.64 \mathrm{~m}$, $9.63 \mathrm{~m}$ and $13.65 \mathrm{~m}$, respectively. The floor type is basalt paving stone coating. There are two breakwaters on the upstream front of the bridge legs. Different views and geometrical properties of the Kalender Bridge can be seen in Fig. 7 and Fig. 8, respectively.

\section{Numerical modelling of the bridge}

There are various modeling techniques for masonry structures but three of them are commonly used for numerical finite element modeling of masonry structures. They are called detailed micro, simplified micro, and macro modeling. These modeling approaches can be seen in Fig. 9. In the detailed micro modeling, the material properties of the masonry units and the mortar are considered

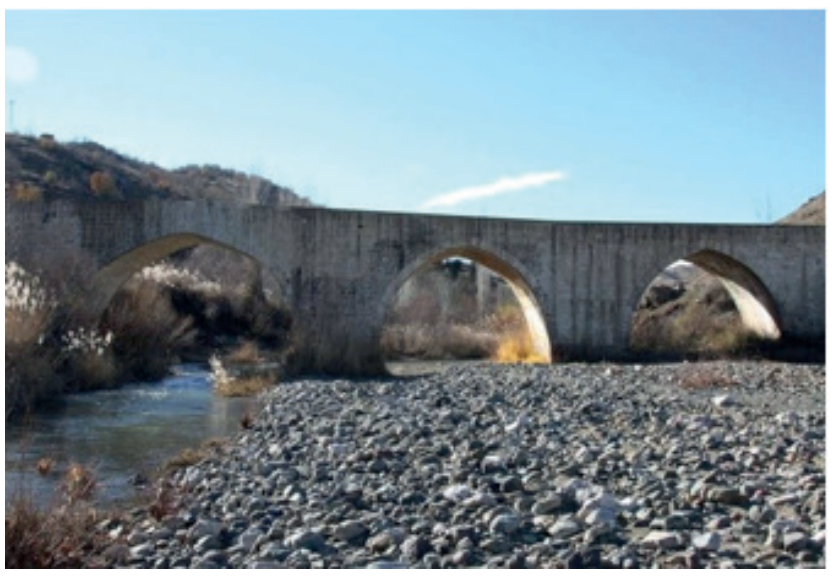

(a) Downstream view

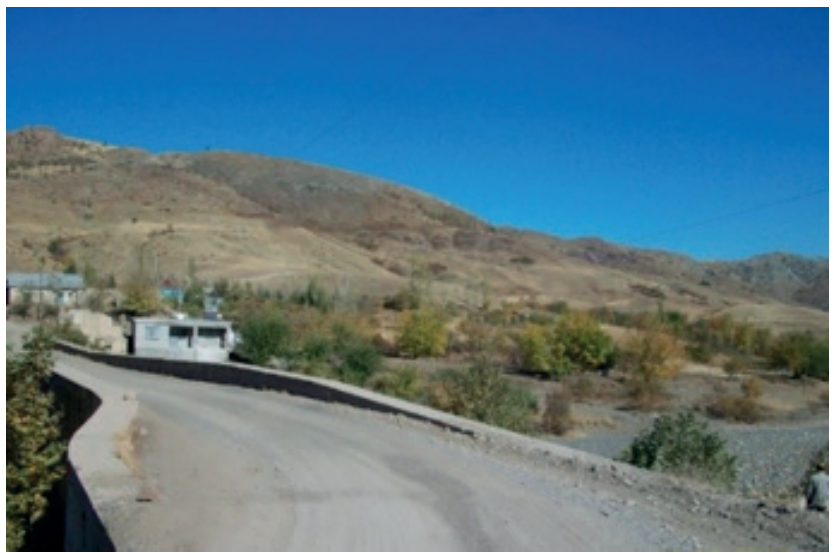

(c) Bridge floor separately. The dimension of the masonry unit is extended as much as half thickness of the mortar in the simplified micro modelling. Thus, the masonry units are separated from each other with interface lines and the mortar layer is neglected. There is no separation between the masonry unit and mortar in the macro-modeling approach. The masonry unit and mortar are accepted as a composite material without making a distinction between unit and mortar in this approach [19].

According to the literature, macro-modeling approach is more useful for large scale structure models because of low computational effort [20-22]. This approach was used in many studies [23-27].

In this study, the bridge was modelled with macro modelling approach. Three dimensional (3D) finite element model of the bridge was generated with ANSYS finite element software. 31621 nodes and 15477 solid elements were used in three-dimensional finite element model of the Kalender Bridge (Fig. 10). In the finite element modelling, SOLID65 element which is capable of cracking in

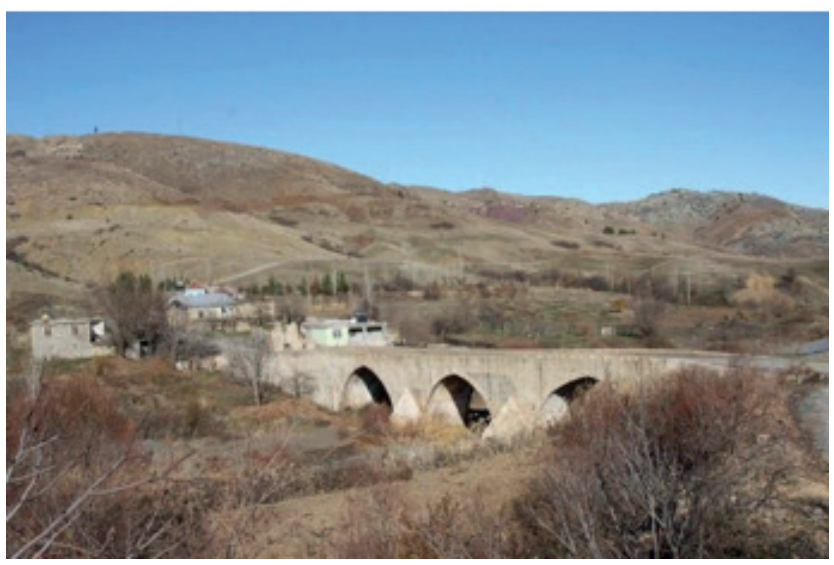

(b) Upsteram view

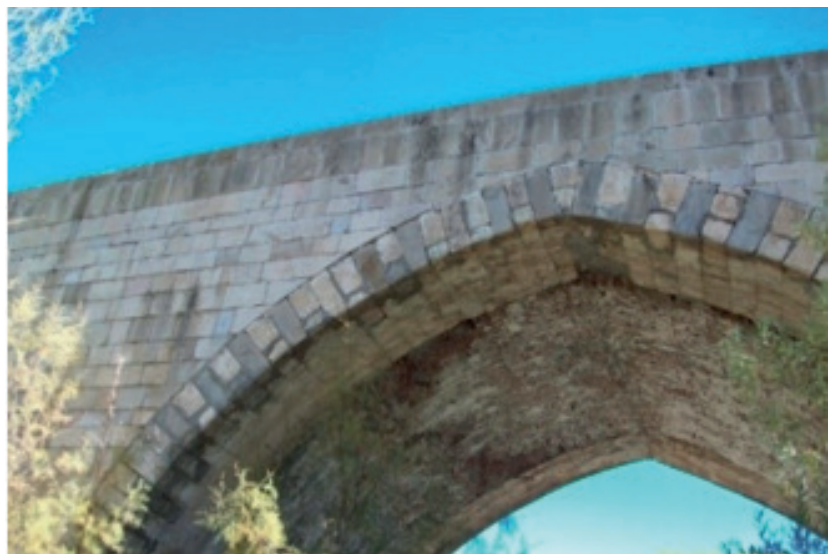

(d) Brick filling material inside the arch

Fig. 7 Different views of historical masonry Kalender bridge 


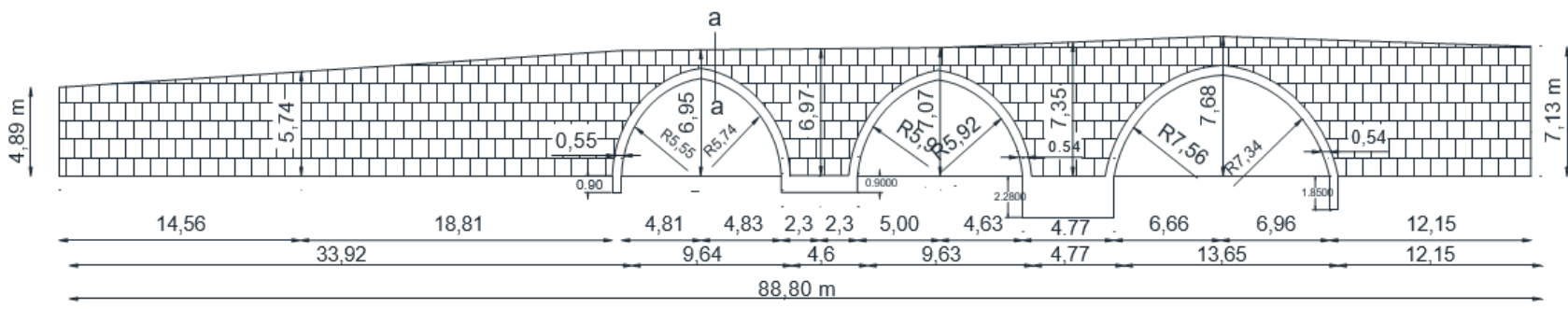

(a) Front view

$88,8 \mathrm{~m}$

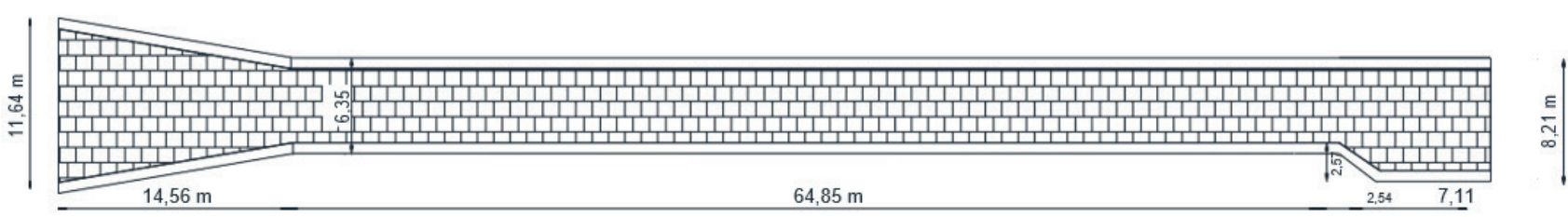

(b) Plan view

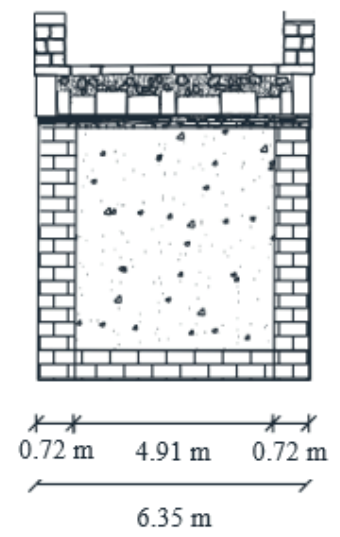

(c) Section a-a

Fig. 8 Geometrical properties of historical masonry Kalender Bridge
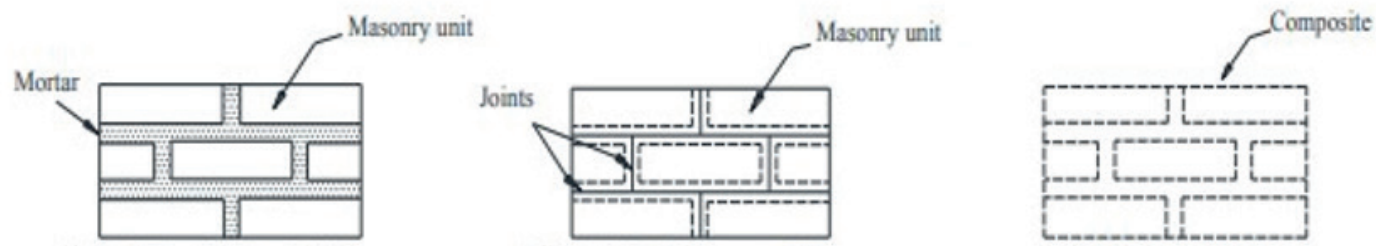

Fig. 9 Different modelling strategies of masonry structures (a) Detailed micro-modelling; (b) Simplified micro-modelling; (c) Macro-modelling

tension and crushing in compression is used. The element has 8 nodes and has 3 translation degrees of freedom on $\mathrm{x}$, $\mathrm{y}$ and $\mathrm{z}$ directions. Also, the element is used many different numerical studies to assessment the nonlinear behavior of masonry structures [21, 26, 28, 29]. The SOLID65 element allow nonlinear response for brittle materials depends upon a constitutive model for triaxial behavior of concrete $[30,31]$. The element uses a smeared crack analogy for cracking in tension zones and considers plasticity algorithm for crushing in compression zones. Smeared crack approach is selected for nonlinear behavior of the arches and spandrel walls. Drucker-Prager material model is also used for elastic-plastic behavior of the fill material. The Drucker-Prager criterion is a simple modification of the Von Mises criterion which includes the effect of hydrostatic stress. The Drucker-Prager surface which express depending on the cohesion and the friction angle is like a right-circular cone. The yield surface is given in Fig. 11 [28].

In the finite element model of the bridge, all degrees of freedom were assumed to be fixed at foundation level. Solid element sizes of the finite element model were varied from $0.5 \mathrm{~m} \times 0.5 \mathrm{~m} \times 0.5 \mathrm{~m}$ to $1 \mathrm{~m} \times 1 \mathrm{~m} \times 1 \mathrm{~m}$. The three- 


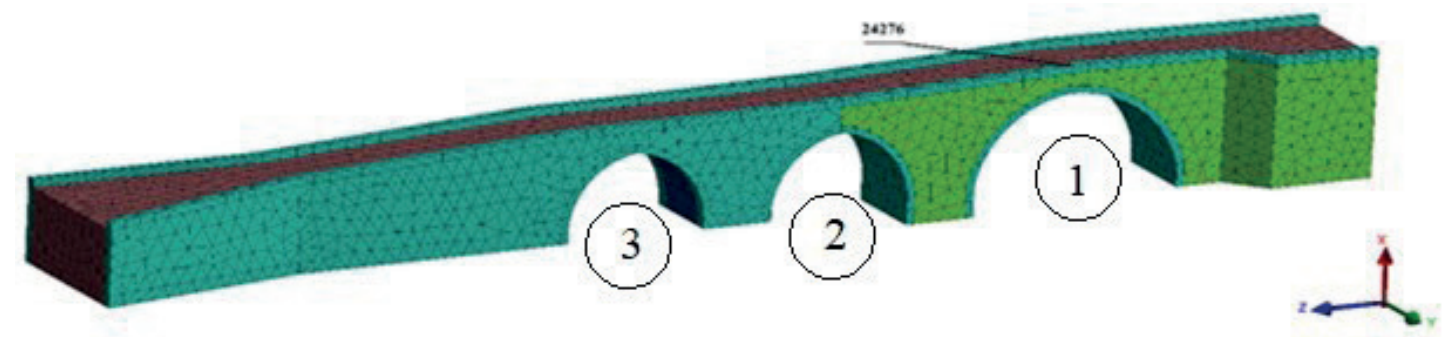

(a)

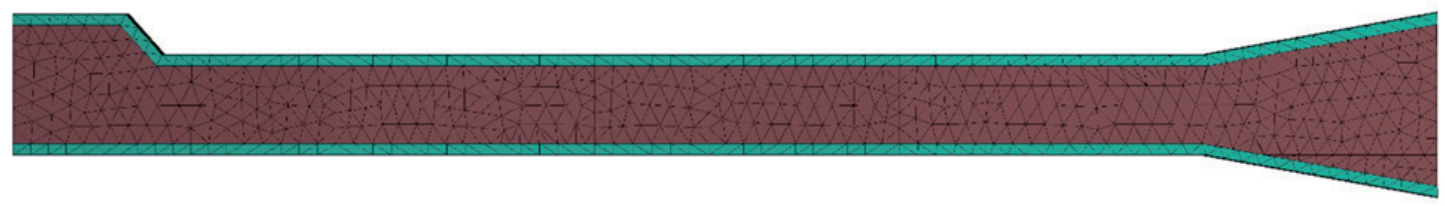

(b)

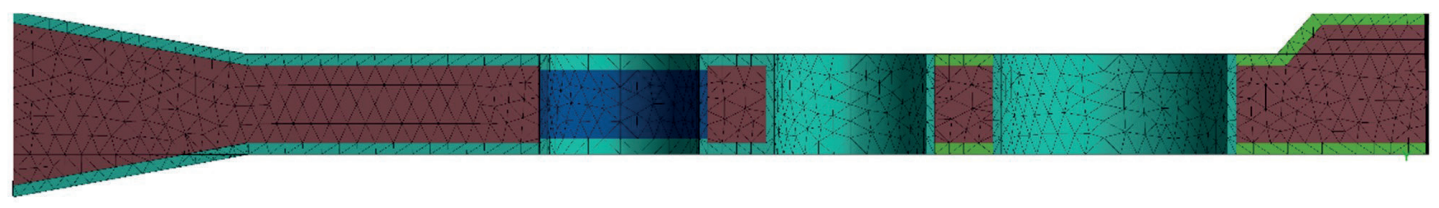

(c)

Fig. 10 Finite element model of the historical masonry Kalender Bridge

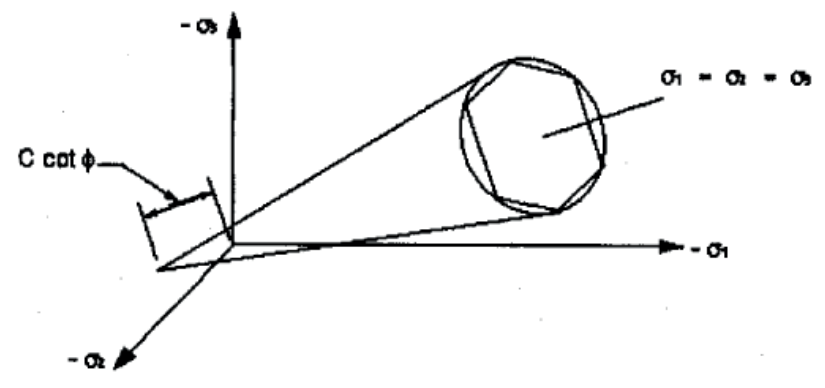

Fig. 11 Drucker-Prager fill material model [28]

dimensional finite element model of the historical Kalender Bridge and the node 24276 are given in Fig. 10. In Fig. 10, dark green, bright green, brown and blue colors represent Material-1, 2, 3 and 4, respectively. Material-1 and 2 represents old and restoration stone sets, respectively. Material-2 belongs to restoration period of the bridge. Material-3 and 4 represents brick filling and filling material, respectively. Four different material sets are shown in Fig. 12. In this figure, Material-4 does not appear because of filling material. Material properties (i.e. young modulus, poisson ratio, unit weight) of the masonry arch Kalender Bridge are presented in Table 2. The average mechanical material properties of the masonry units are selected from the relevant literature [31-36].

Also, compressive strength of Material-1 and Material-2 were obtained as 20 and $15 \mathrm{MPa}$ by the 8th Regional Directorate of Highways. According to the previous stu-

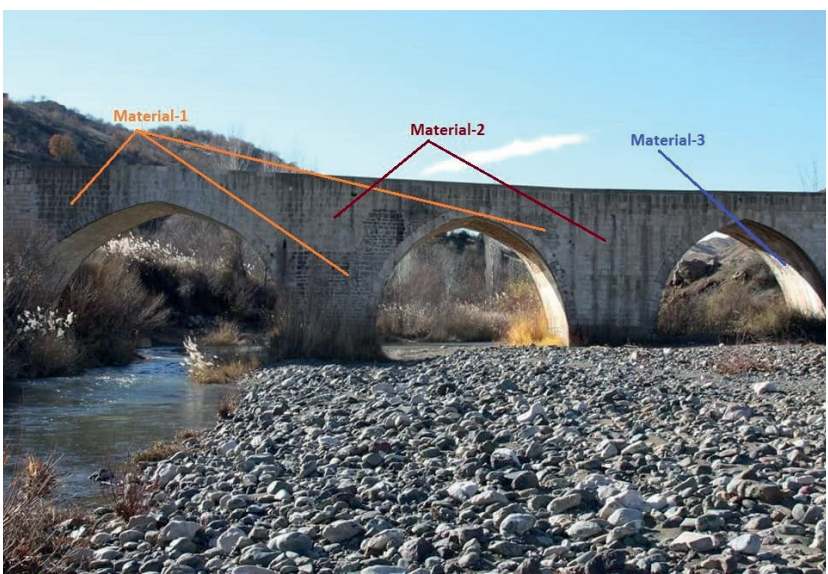

Fig. 12 Historical masonry Kalender Bridge and different material sets used in the bridge

Table 2 Material properties of Kalender Bridge

\begin{tabular}{lccccccc}
\hline Material & $\begin{array}{c}E \\
(\mathrm{Mpa})\end{array}$ & $\begin{array}{c}\gamma \\
\left(\mathrm{t} / \mathrm{m}^{3}\right)\end{array}$ & $v$ & $\begin{array}{c}f_{t} \\
(\mathrm{Mpa})\end{array}$ & $\begin{array}{c}f_{c} \\
(\mathrm{Mpa})\end{array}$ & $\begin{array}{c}C \\
(\mathrm{Mpa})\end{array}$ & $\begin{array}{c}\varnothing \\
(\mathrm{o})\end{array}$ \\
\hline Material-1 & 6000 & 2.3 & 0.20 & 2 & 20 & - & - \\
Material -2 & 5000 & 2.2 & 0.20 & 1.5 & 15 & - & - \\
Material- 3 & 1200 & 1.8 & 0.20 & - & - & 0.58 & 55 \\
Material- 4 & 500 & 1.4 & 0.20 & - & - & 0.35 & 40 \\
\hline
\end{tabular}

dies, tensile strength of the stone is accepted as $1 / 10$ of the compressive strength $[6,7,36]$. Thus, tensile strength of Material-1 and Material-2 are considered as 2 and 1.5 MPa, respectively. 


\section{Analyses results of near-fault and far-fault ground motions}

Dynamic analysis of the historical Kalender Bridge was performed under the near-fault and far-fault ground motions. Newmark algorithm was used in the solution of the equation of motion. The viscous damping ratio was considered as $5 \%$ in the dynamic analysis as being proportional to the stiffness and mass matrices. Earthquake accelerations were applied by the y axis, which is the weak axis of the bridge. Only the most effective 15 seconds of the earthquake records was considered in the analyses.

Displacements of the nodal point 27276 are compared in terms of near and far-fault ground motions. Displacement values of the nodal point in the $\mathrm{x}, \mathrm{y}$ and $\mathrm{z}$ directions are given in Figs. 13-16 for near and far-fault ground motions of 1979 Imperial Valley, 1999 Kocaeli, 1999 Chi-Chi and 2010 Darfield earthquakes, respectively. As seen from the analysis results (Figs. 13-16), the maximum displacements were found as $3.60 \mathrm{~mm}$ and $3.92 \mathrm{~mm}$ for 1999 Chi-Chi near fault and 1979 Imperial Valley far fault earthquakes in the y direction, respectively. Also, the comparisons of the peak displacements are given in Table 3 for the historical bridge. When the peak displacements of near and far-fault earthquakes are compared, it can be seen that far-fault effects in the displacement is greater than the near-fault effects at majority of the selected earthquakes ground motions (1979 Imperial Valley, 1999 Chi-Chi, 2010 Darfield). In the 1999 Kocaeli earthquake, near-fault effect in the displacement gives greater values in comparison with far-fault effect. Variation in the maximum displacements along the bridge in y direction for 1979 Imperial Valley, 1999 Kocaeli, 1999 Chi-Chi and 2010 Darfield earthquake ground motions are shown in Fig. 17. It can be seen from Fig. 17 that maximum displacements are occurred under far- fault ground
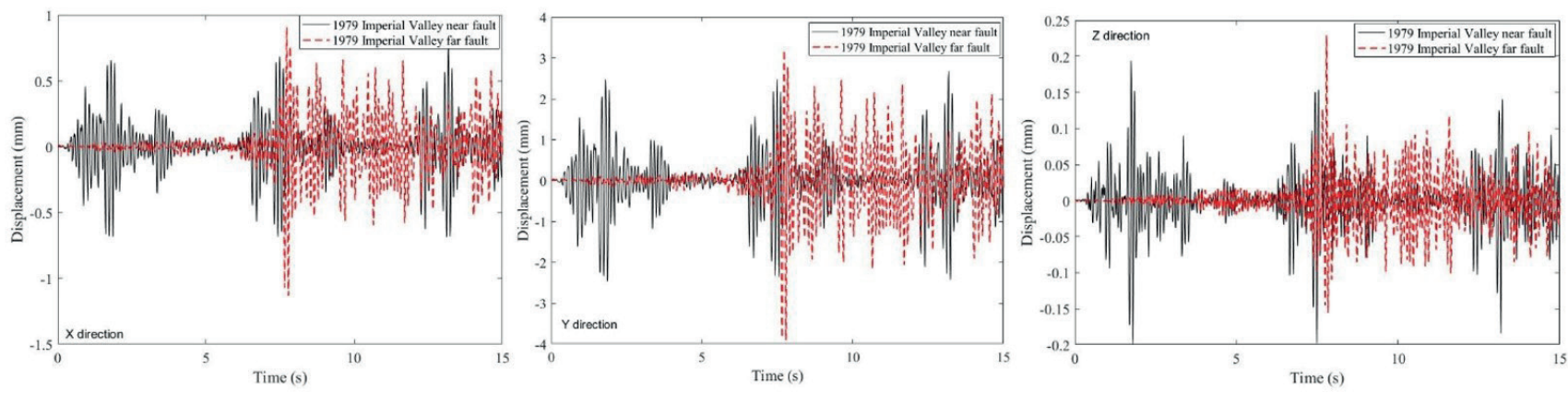

Fig. 13 Time histories of the displacement of the nodal point 27276 for 1979 Imperial Valley earthquake
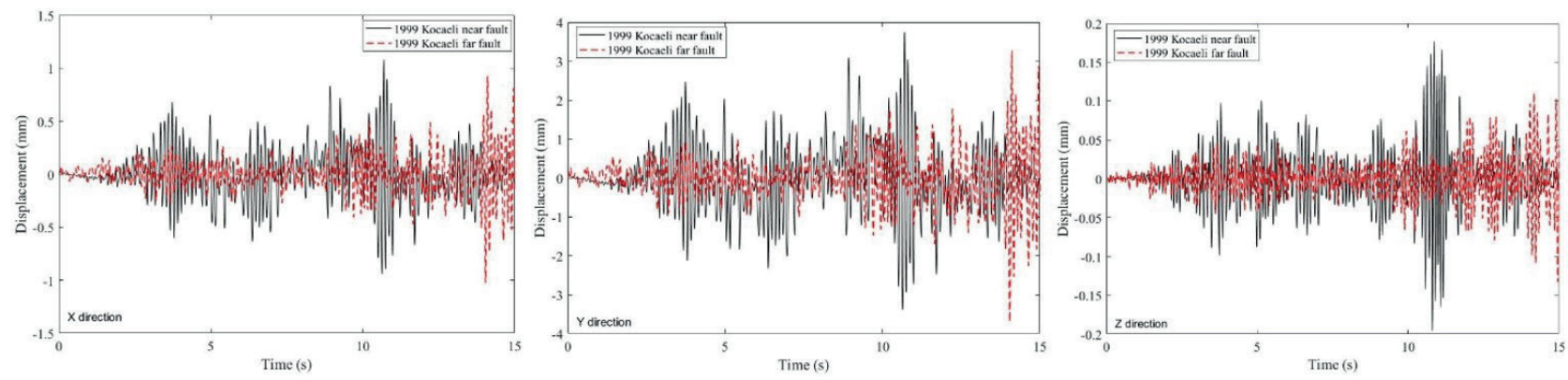

Fig. 14 Time histories of the displacement of the nodal point 27276 for 1999 Kocaeli earthquake
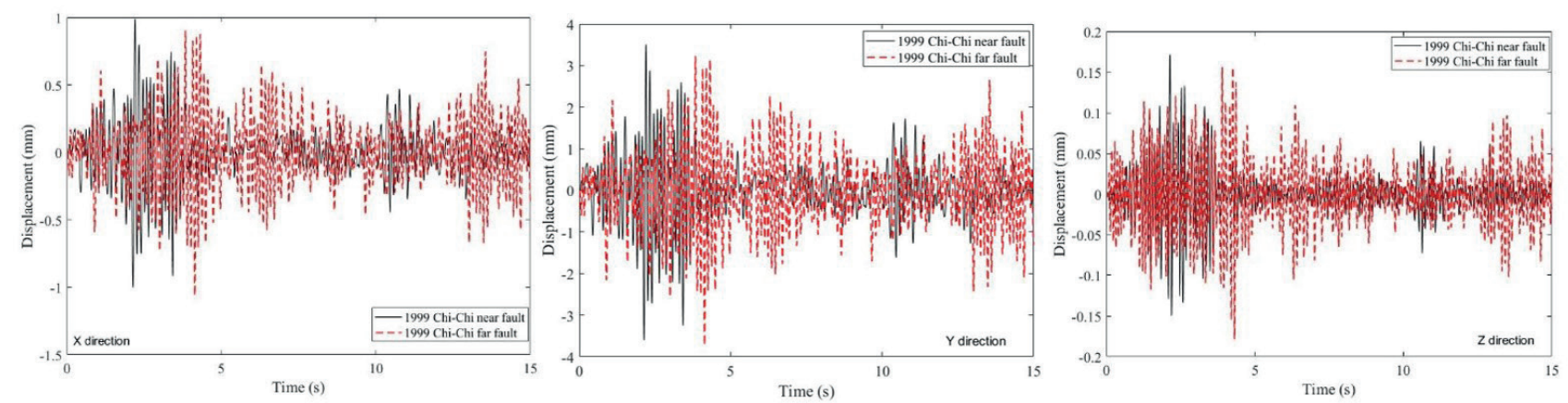

Fig. 15 Time histories of the displacement of the nodal point 27276 for 1999 Chi-Chi earthquake 

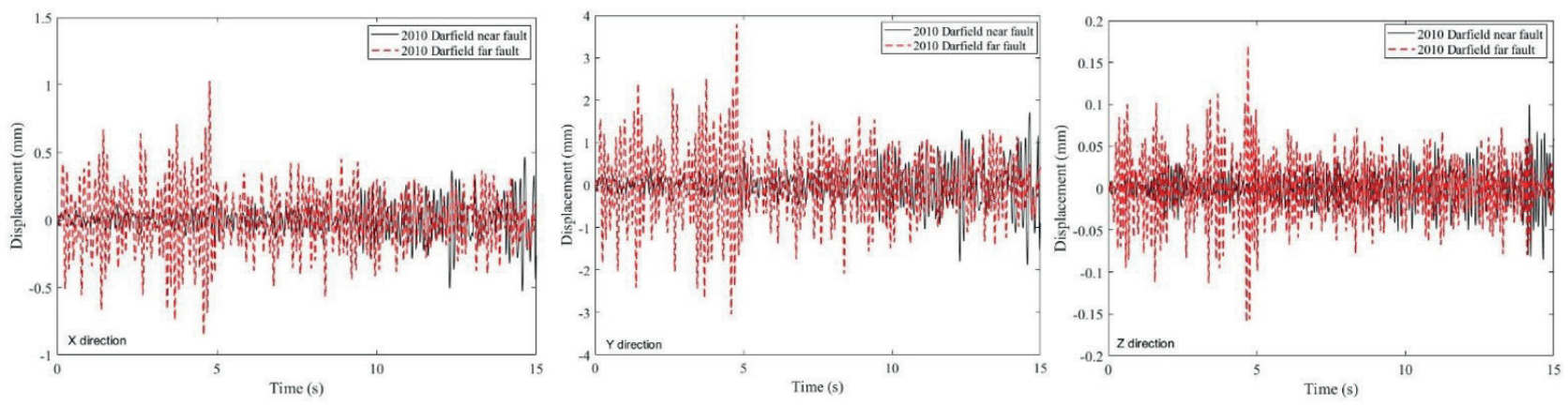

Fig. 16 Time histories of the displacement of the nodal point 27276 for 2010 Darfield earthquake

Table 3 Comparison of peak displacements of near and far-fault earthquakes

\begin{tabular}{lccc}
\hline Earthquake & $\mathrm{x}$ direction $(\mathrm{mm})$ & $\mathrm{y}$ direction $(\mathrm{mm})$ & $\mathrm{z}$ direction $(\mathrm{mm})$ \\
\hline 1979 Imperial Valley Near-fault & 0.76 & 2.68 & 0.19 \\
1979 Imperial Valley Far-fault & 1.13 & 3.92 & 0.22 \\
1999 Kocaeli Near-fault & 1.08 & 3.75 & 0.20 \\
1999 Kocaeli Far -fault & 1.02 & 3.70 & 0.13 \\
1999 Chi-Chi Near-fault & 1.005 & 3.60 & 0.17 \\
1999 Chi-Chi Far-fault & 1.06 & 3.73 & 0.18 \\
2010 Darfield Near-fault & 0.53 & 1.88 & 0.14 \\
2010 Darfield Far-Fault & 1.03 & 3.79 & 0.17 \\
\hline
\end{tabular}
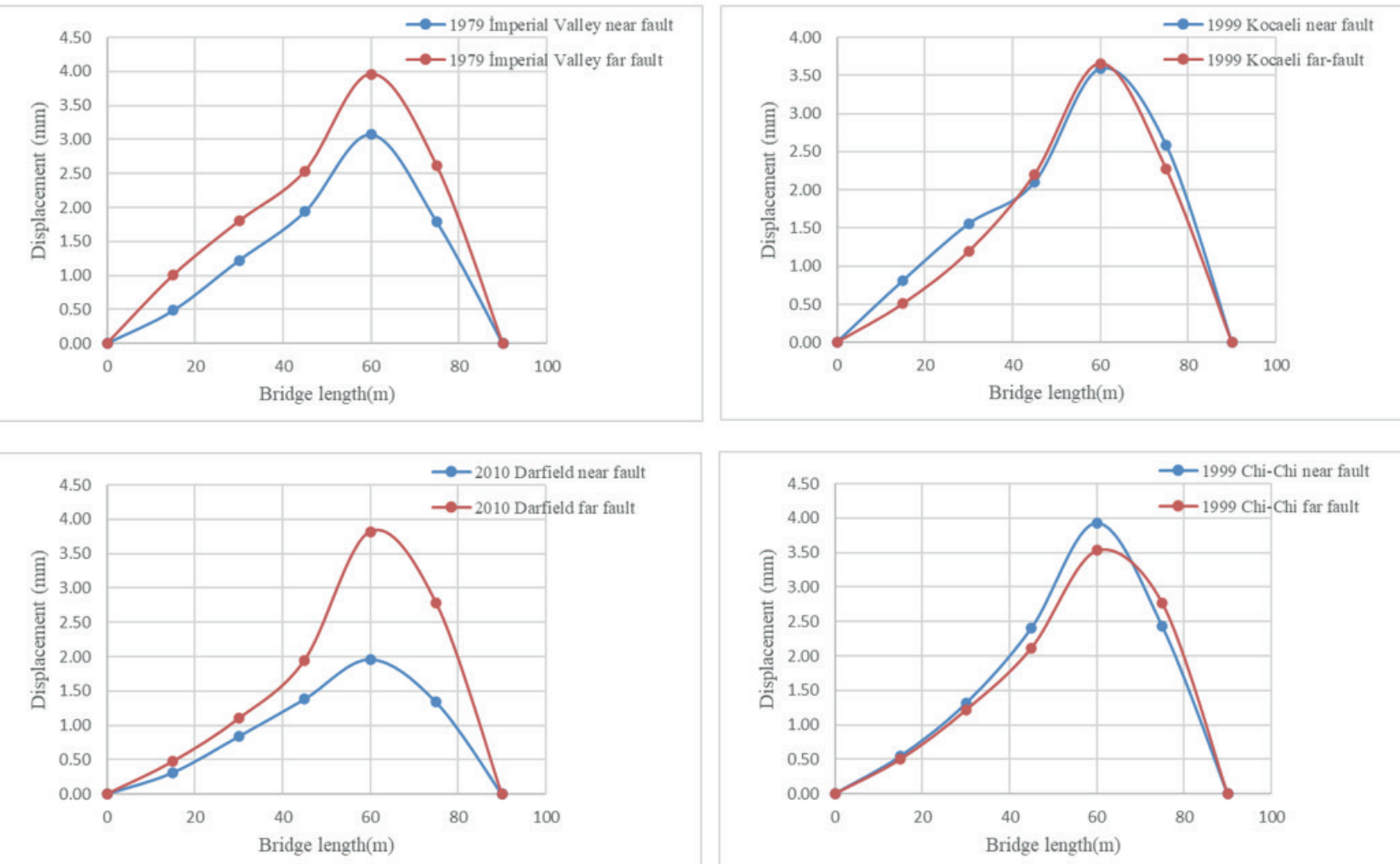

Fig. 17 Comparison of maximum displacements along the bridge length in y direction 
motion records for 1979 Imperial Valley and 2010 Darfield earthquake along the length of the bridge. Maximum displacements are very close to each other for 1999 Kocaeli and 1999 Chi-Chi earthquake for near-fault and far-fault records. The maximum and minimum principal stresses attained from 1979 Imperial Valley, 1999 Kocaeli, 1999 Chi-Chi and 2010 Darfield earthquakes ground motions are given in Table 4. Maximum and minimum principal stress contours obtained from 1979 Imperial Valley near and farfault earthquake records are shown in Fig. 18. It can be seen that minimum and maximum principal stress are obtained at left side of the first arch base at downstream face of the bridge for the near far fault records of 1979 Imperial Valley earthquake. For far fault records of the same earthquake, minimum principal stress is obtained at right side of the first arch base at upstream face of the bridge.

For 1999 Kocaeli near and far fault earthquake records, maximum and minimum principal stress contours are shown in Fig. 19. It can be seen that maximum and minimum principal stress is occurred at left side of the first and second arch base at downstream face of the bridge for the near fault records of 1999 Kocaeli earthquake.

Table 4 Maximum and minimum principal stresses values for near and far-fault

\begin{tabular}{|c|c|c|c|c|}
\hline \multirow[b]{2}{*}{ Earthquake Name } & \multicolumn{2}{|c|}{ Maximum Principal Stress (MPa) } & \multicolumn{2}{|c|}{ Minimum Principal Stress (MPa) } \\
\hline & Near-fault & Far-fault & Near-fault & Far-fault \\
\hline 1979 Imperial Valley & 1.65 & 2.29 & 1.69 & 2.25 \\
\hline 1999 Kocaeli & 2.02 & 2.09 & 2.03 & 2.05 \\
\hline 1999 Chi-Chi & 2.19 & 2.01 & 2.13 & 1.99 \\
\hline 2010 Darfield & 1.06 & 2.11 & 1.09 & 2.18 \\
\hline
\end{tabular}

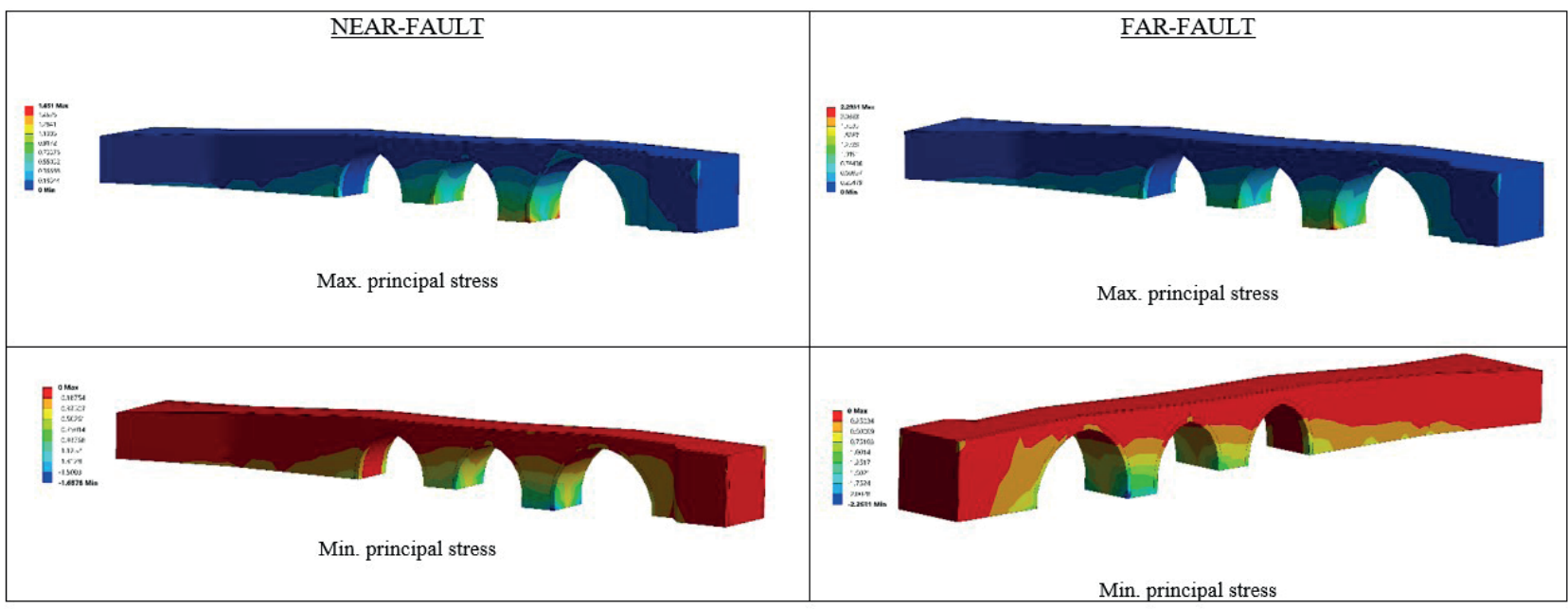

Fig. 18 Maximum and minimum principal stress contours due to 1979 Imperial Valley near and far-fault earthquakes

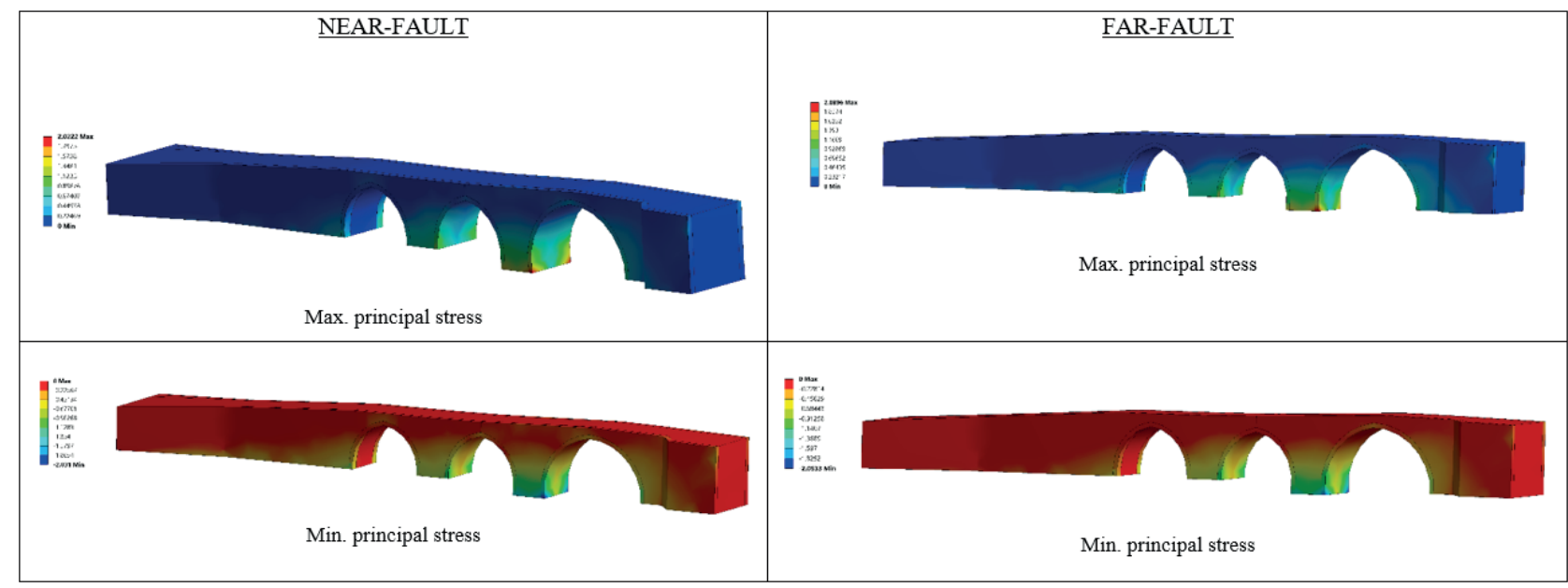

Fig. 19 Maximum and minimum principal stress contours due to 1999 Kocaeli near and far-fault earthquakes 
For far-fault records of 1999 Kocaeli earthquake, maximum principal and minimum principal stress is occurred at left side of the first and middle arch base at upstream face of the first arch base at downstream face of the bridge.

Maximum and minimum principal stress contours are shown in Fig. 20 for 1999 Chi-Chi near and far-fault earthquake records. It can be seen that maximum principal stress are obtained at left side of the first and middle arch base at downstream face of the bridge and minimum principal stress is occurred at right side of the first and second arch base at upstream face of the bridge for the near-fault records of 1999 Chi-Chi earthquake. Maximum and minimum principal stress is occurred right side of the first and second arch base at downstream face of the bridge for the far-fault records of 1999 Chi-Chi earthquake.
Maximum and minimum principal stress contours acquired from 2010 Darfield near and far-fault earthquake records are shown in Fig. 21. Maximum and minimum principal stresses are occurred at left side of the first and second arch base at downstream face of the bridge for the near-fault records of 2010 Darfield earthquake. For far-fault records of 2010 Darfield earthquake, maximum principal stress is occurred right side of the first and middle arch base at upstream face of the bridge and minimum principal stress is acquired at left side of the first and middle arch base at downstream face of the bridge for the farfault records of 2010 Darfield earthquake.

When the analysis results are investigated, compressive strength of the stone was not exceeded for all investigated near and far-fault earthquakes. But the tensile strength of

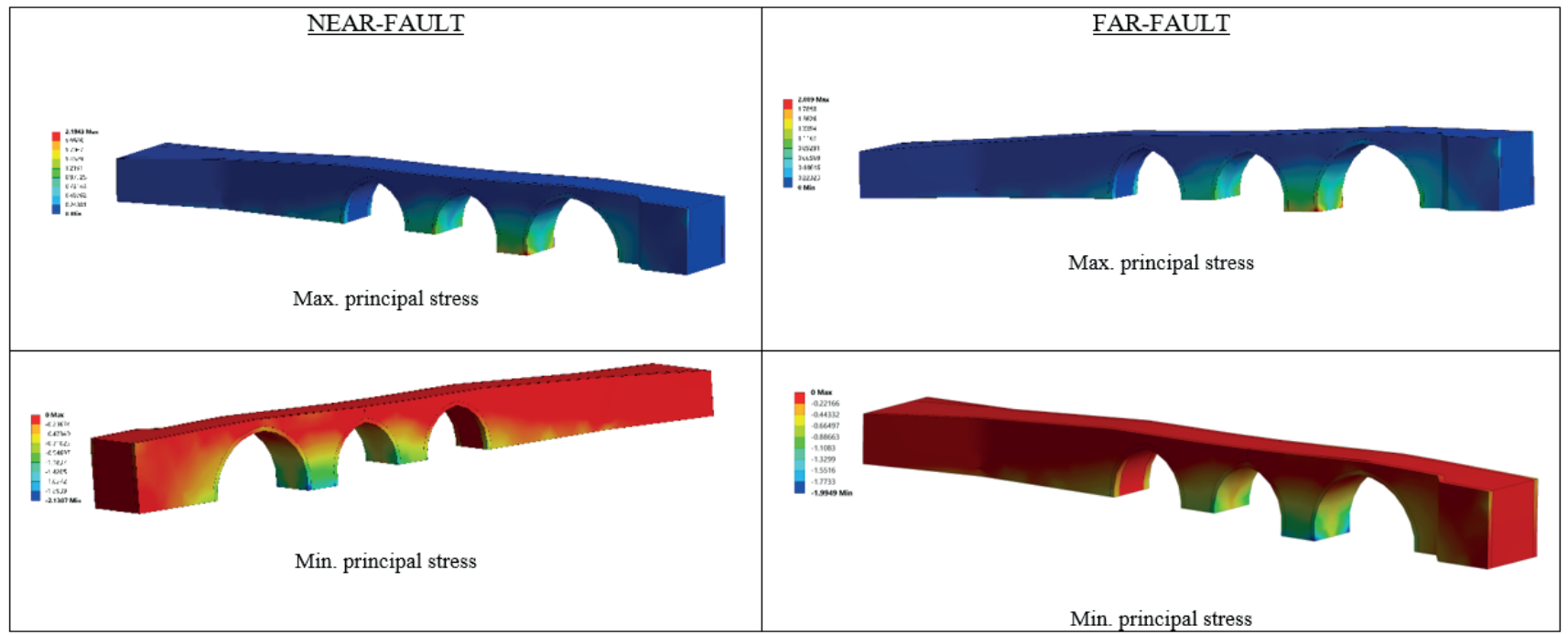

Fig. 20 Maximum and minimum principal stress contours due to 1999 Chi-Chi near and far-fault earthquakes

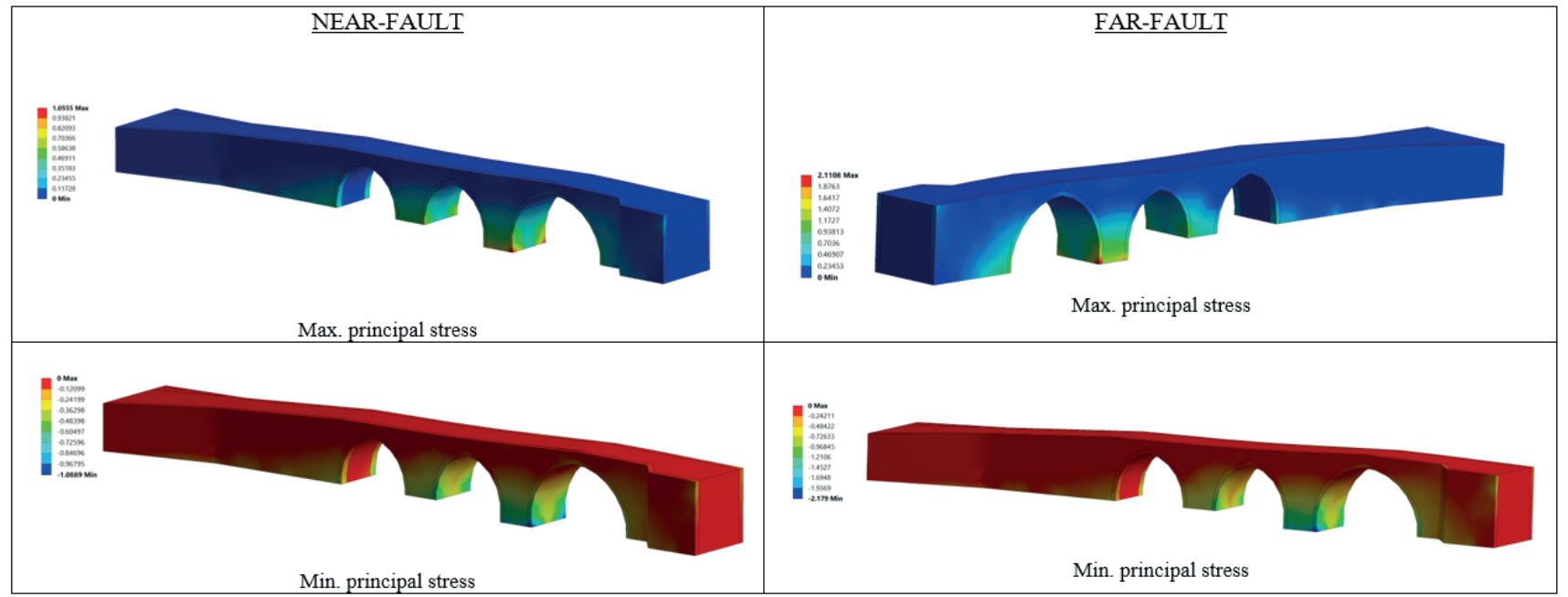

Fig. 21 Maximum and minimum principal stress contours due to 2010 Darfield near and far-fault earthquakes 
the stone was exceeded for all investigated earthquakes except the 2010 Darfield near-fault earthquake. However, the obtained tensile stress in the analyses is close to the tensile strength of the stone. Therefore, in regions where the tensile strength of the stone was exceed, probable cracks and damages may be observed.

\section{Conclusions}

In this paper, the seismic response of a historical bridge was evaluated for four different near-fault and far-fault ground motions. For this purpose, Kalender historical masonry bridge was chosen as a numerical example and modelled with three dimensional finite element method. For each strong ground motion record, time-history analysis was performed and seismic responses of the bridge were evaluated. As a result of these analyses, the following results were achieved.

- When the absolute maximum displacements obtained from the nodal point 24276 were compared in the $\mathrm{x}$, $y$ and $z$ directions of the bridge, the far-fault earthquake results were higher than near-fault earthquake results for 1979 Imperial Valley, 1999 Chi-Chi, and 2010 Darfield earthquakes. However, the near-fault earthquake results were higher than far-fault earthquake results for 1999 Kocaeli earthquake.

- Also, it was seen that the maximum displacements values were higher for the far-fault ground motions compared to the near-fault ground motions when considering the maximum displacements obtained from the same nodes along the length of the bridge for 1979 Imperial Valley, 2010 Darfield earthquakes.

\section{References}

[1] Özmen, A., Sayın, E. "Seismic assessment of a historical masonry arch bridge", Journal of Structural Engineering \& Applied Mechanics, 1(2), pp. 95-104, 2018.

https://doi.org/10.31462/jseam.2018.01095104

[2] Liao, W.-I., Loh, C.-H., Lee, B.-H. "Comparison of dynamic response of isolated and non-isolated continuous girder bridges subjected to near-fault ground motions", Engineering Structures, 26(14), pp. 2173-2183, 2014.

https://doi.org/10.1016/j.engstruct.2004.07.016

[3] Galal, K., Ghobarah, A. "Effect of near-fault earthquakes on North American nuclear design spectra", Nuclear Engineering and Design, 236, pp. 1928-1936, 2006.

https://doi.org/10.1016/j.nucengdes.2006.02.002

[4] Bayraktar, A., Altunişik, A. C., Sevim, B., Kartal, M. E., Türker, T. "Near-fault ground motion effects on the nonlinear response of dam- reservoir-foundation systems", Structural Engineering and Mechanics, 28(4), pp. 411-442, 2008.

https://doi.org/10.12989/sem.2008.28.4.411
However, the results are very close to each other for the 1999 Chi-Chi and 1999 Kocaeli earthquakes. In addition, the maximum displacement values were obtained from far-fault ground motion of the 1979 Imperal Valley earthquake.

- When maximum principal stresses were compared for far-fault earthquakes, the obtained results were close to each other. The highest stress value was obtained from 1979 Imperial Valley earthquake. For near-fault ground motions, highest stress value was obtained from 1999 Chi-Chi earthquake for maximum principal stress.

- When minimum principal stress was compared for far-fault earthquakes the obtained results were close to each other. The highest stress value was again obtained from 1979 Imperial Valley earthquake. For near-fault ground motions, highest and lowest stress values were obtained from 1999 Chi-Chi earthquake and 2010 Darfield earthquake for minimum principal stress, respectively. According to the results of this study, far-fault ground motions are important as much as near-fault ground motions for the seismic assessments of historical masonry arch bridges. In the future studies related to earthquake responses of historical masonry arch bridges, far-fault ground motions could be taken into account with near-fault ground motions.

\section{Acknowledgement}

This study was supported by the Firat University Research Project (FUBAP) under project number MF.19.10.

[5] Chopra, A. K., Chintanapakdee, C. "Comparing response of SDF systems to near-fault and far-fault earthquake motions in the context of spectral regions", Earthquake Engineering and Structural Dynamics, 30, pp. 1769-1789, 2001.

https://doi.org/10.1002/eqe.92

[6] Güllü, H., Karabekmez, M. "Effect of near-fault and far-fault earthquakes on a historical masonry mosque through 3D dynamic soil-structure interaction", Engineering Structures, 152, pp. 465492, 2017.

https://doi.org/10.1016/j.engstruct.2017.09.031

[7] Bayraktar, A., Hökelekli, E. "Nonlinear soil deformability effects on the seismic damage mechanisms of brick and stone masonry arch bridges", International Journal of Damage Mechanics, 30(3), pp. 431-452, 2020. https://doi.org/10.1177/1056789520974423 
[8] Zhang, S., Wang, G. "Effects of near-fault and far-fault ground motions on nonlinear dynamic response and seismic damage of concrete gravity dams", Soil Dynamic Earthquake Engineering, 53, pp. 217-229, 2013. https://doi.org/10.1016/j.soildyn.2013.07.014

[9] Adanur, S., Altunişik, A. C., Bayraktar, A., Akköse, M. "Comparison of near-fault and far-fault ground motion effects on geometrically nonlinear earthquake behavior of suspension bridges", Natural Hazards, 64, pp. 593-614, 2012. https://doi.org/10.1007/s11069-012-0259-5

[10] Cao, V. V., Ronagh, H. R. "Correlation between seismic parameters of far-fault motions and damage indices of low-rise reinforced concrete frames", Soil Dynamics and Earthquake Engineering, 66, pp. 102-112, 2014. https://doi.org/10.1016/j.soildyn.2014.06.020

[11] Davoodi, M., Jafari, M. K., Hadiani, N. "Seismic response of embankment dams under near-fault and far-field ground motion excitation", Engineering Geology, 158, pp. 66-76, 2013. https://doi.org/10.1016/j.enggeo.2013.02.008

[12] Kramer, S. L. "Geotechnical Earthquake Engineering", Prentice Hall, Upper Saddle River, NJ, USA, 1996.

[13] Bayülke, N. "Multi-storey buildings and earthquake", In: MultiStorey Buildings Symposium, İzmir, Turkey, 1989. (in Turkish)

[14] Akkar, S., Yazgan, U., Gülkan, P. "Drift estimates in frame buildings subjected to near-fault ground motions", Journal of Structural Engineering, 131, pp. 1014-1024, 2005. https://doi.org/10.1061/(ASCE)0733-9445(2005)131:7(1014)

[15] Disaster and Emergency Management Presidency "Turkish Accelerometric Database", [online] Available at: https://tadas.afad. gov.tr/ [Accessed: 15 April 2019]

[16] The Pacific Earthquake Engineering Research Center "PEER NGA-West2", [online] Available at: https://ngawest2.berkeley.edu/ [Accessed: 18 April 2020]

[17] Seismosoft Ltd. "Seismomatch (2018)" [online] Available at: https:// seismosoft.com/product/seismomatch/ [Accessed: 18 April 2020]

[18] KGM, 8th Regional Directorate of Highways "Historical Bridges Inventory Brochure", Elazığ, Turkey, 2017. (in Turkish) [online] Available at: https://www.kgm.gov.tr/

[19] Lourenço, P. B. "Computational strategies for masonry structures", PhD Thesis, Delft Technical University of Technology, 1996.

[20] Carpinteri, A., Invernizzi S., Lacidogna G. "In situ damage assessment and nonlinear modelling of a historical masonry tower", Engineering Structures, 27(3), pp. 387-395, 2005. https://doi.org/10.1016/j.engstruct.2004.11.001

[21] Sayin, E. "Nonlinear seismic response of a masonry arch bridge", Earthquakes and Structures, 10(2), pp. 483-494, 2016. https://doi.org/10.12989/eas.2016.10.2.483

[22] Karaton, M., Aksoy, H. S. "Seismic Damage Assessment of an 891 Years Old Historic Masonry Mosque", Periodica Polytechnica Civil Engineering, 62(1), pp. 126-135, 2018.

https://doi.org/10.3311/PPci.10270

[23] Sevim, B., Bayraktar, A., Altunışık, A. C., Atamtürktür, S., Birinci, F. "Finite element model calibration effects on the earthquake response of masonry arch bridges", Finite Elements in Analysis and Design, 47, pp. 621-634, 2011.

https://doi.org/10.1016/j.finel.2010.12.011
[24] Altunışık, A. C., Kanbur, B., Genç, A. F. "The effect of arch geometry on the structural behavior of masonry bridges", Smart Structures and Systems, 16, pp. 1069-1089, 2015.

https://doi.org/10.12989/sss.2015.16.6.1069

[25] Hokelekli, E., Y1lmaz, B. N. "Effect of Cohesive Contact of Backfill with Arch and Spandrel Walls of a Historical Masonry Arch Bridge on Seismic Response", Periodica Polytechnica Civil Engineering, 63(3), pp. 926-937, 2019. https://doi.org/10.3311/PPci.14198

[26] Karaton, M., Aksoy, H. S., Sayın, E., Calayır, Y. "Nonlinear seismic performance of a 12th century historical masonry bridge under different earthquake levels", Engineering Failure Analysis, 79, pp. 408-421, 2017. https://doi.org/10.1016/j.engfailanal.2017.05.017

[27] Erdil, B., Tapan, M., Akkaya, İ., Korkut, F. "Effects of Structural Parameters on Seismic Behaviour of Historical Masonry Minaret", Periodica Polytechnica Civil Engineering, 62(1), pp. 148-161, 2018. https://doi.org/10.3311/PPci.10687

[28] Fanning, P. J., Boothby, T. E. "Three-dimensional modelling and full-scale testing of stone arch bridges", Computers \& Structures, 79(29-30), pp. 2645-2662, 2001.

https://doi.org/10.1016/S0045-7949(01)00109-2

[29] Li, T., Atamturktur, S. "Fidelity and Robustness of Detailed Micromodeling, Simplified Micromodeling, and Macromodeling Techniques for a Masonry Dome", Journal of Performance of Constructed Facilities, 28(3), pp. 480-490, 2014. https://doi.org/10.1061/(ASCE)CF.1943-5509.0000440

[30] William K. J., Warnke E. D. "Constitutive model for the tri-axial behavior of concrete", In: Proceeding of the International Association for Bridge and Structural Engineering, 19, ISMES, Bergamo, Italy, 1975, pp. 1-30.

[31] ANSYS "Finite Element Software", Swanson Analysis Systems Inc., Houston, TX, USA, 2015. [online] Available at: https://www. ansys.com/

[32] Pelà, L., Aprile, A., Benedetti, A. "Seismic assessment of masonry arch bridges", Engineering Structures, 31(8), pp. 1777-1788, 2009. https://doi.org/10.1016/j.engstruct.2009.02.012

[33] Bayraktar, A., Hökelekli, E. "Seismic Performances of Different Spandrel Wall Strengthening Techniques in Masonry Arch Bridges", International Journal of Architectural Heritage, 2020. https://doi.org/10.1080/15583058.2020.1719234

[34] Wang, J. "Numerical modelling of masonry arch bridges: Investigation of spandrel wall failure", $\mathrm{PhD}$ Thesis, University of Bath, 2014.

[35] Valente, M., Milani, G. "Seismic assessment of historical masonry towers by means of simplified approaches and standard FEM", Construction and Building Materials, 108, pp. 74-104, 2016. https://doi.org/10.1016/j.conbuildmat.2016.01.025

[36] Baykasoğlu, A., Güllü, H., Çanakçı, H., Özbakır, L. "Prediction of compressive and tensile strength of limestone via genetic programming", Expert Systems with Applications, 35(1-2), pp. 111123, 2008.

https://doi.org/10.1016/j.eswa.2007.06.006 